\title{
Erratum to: A qRT-PCR assay for the expression of all Mal $d 1$ isoallergen genes
}

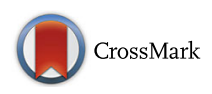

\author{
Giulia Pagliarani ${ }^{1,2^{*} \dagger}$, Roberta Paris ${ }^{2,4 \dagger}$, Paul Arens ${ }^{1}$, Stefano Tartarini ${ }^{2}$, Giampaolo Ricci ${ }^{3}$,
} Marinus J. M. Smulders ${ }^{1}$ and Eric W. Van De Weg ${ }^{1}$

\section{Erratum}

Unfortunately, the original version of this article [1] contained an error. The spelling of the author "Marinus J M Smulders" name was misspelt "Marinus MJ Smulders".

\begin{abstract}
Author details
'Wageningen UR Plant Breeding, Plant Research International, Droevendaalsesteeg 1, Wageningen PB 6708, The Netherlands. ${ }^{2}$ Department of Fruit Tree and Woody Plant Sciences, University of Bologna, Viale Fanin 46, Bologna 40127, Italy. ${ }^{3}$ Department of Paediatrics, University of Bologna, Via Massarenti 11, Bologna 40138, Italy. ${ }^{4}$ Present address: Consiglio per la Ricerca e la sperimentazione in Agricoltura-Centro di Ricerca per le Colture Industriali, via di Corticella 133, Bologna 40128, Italy.
\end{abstract}

Received: 13 March 2016 Accepted: 13 March 2016 Published online: 08 April 2016

\section{References}

1. Pagliarani G, Paris R, Arens P, Tartarini S, Ricci G, Smulders MMJ, Van De Weg EW. A qRT-PCR assay for the expression of all Mal $d 1$ isoallergen genes. BMC Plant Biol. 2013;13:51.

\footnotetext{
*Correspondence: giulia.pagliarani2@unibo.it

${ }^{\dagger}$ Equal contributors

${ }^{1}$ Wageningen UR Plant Breeding, Plant Research International, Droevendaalsesteeg 1, Wageningen PB 6708, The Netherlands

2Department of Fruit Tree and Woody Plant Sciences, University of Bologna, Viale Fanin 46, Bologna 40127, Italy
}

Submit your next manuscript to BioMed Central and we will help you at every step:

- We accept pre-submission inquiries

- Our selector tool helps you to find the most relevant journal

- We provide round the clock customer support

- Convenient online submission

- Thorough peer review

- Inclusion in PubMed and all major indexing services

- Maximum visibility for your research

Submit your manuscript at

www.biomedcentral.com/submit

\section{() Biomed Central}

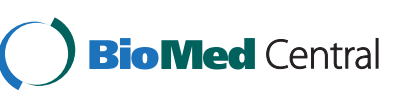

